\title{
Integrating CanMEDS competencies into global health electives: an innovative elective program
}

\author{
Rahim Valani, MD, M Med Ed ${ }^{*}$; Abi Sriharan, MSc, DPhil (c) $)^{\dagger \ddagger}$; Dennis Scolnik, MB, ChB ${ }^{\dagger \ddagger \S}$
}

\section{ABSTRACT}

Globalization has opened the doors for medical students to undertake international health electives, providing an opportunity for them to gain valuable competencies and skills outside their formal curriculum. As the number of medical students embarking on these electives increases, there is a need to structure the electives with specific learning objectives and to ensure adequate educational outcomes.

We describe the International Pediatric Emergency Medicine Elective (IPEME), which is a novel global health elective that brings together students from Canada and the Middle East who are selected on the basis of a competitive application process and brought to Toronto for a 4-week living and studying experience. The program was introduced in 2004 and uses four specific areas to provide its structure: pediatric emergency medicine, global health, leadership, and peace building. The elective uses core CanMEDS competencies to foster cross-cultural dialogue, networking, and cooperation and fulfills the program's aim of using health as a bridge to peace.

The lessons learned from the curriculum planning and implementation process are highlighted and the impact of the program explored to help provide a framework for developing similar international electives.

\section{RÉSUMÉ}

La mondialisation a ouvert les portes aux étudiants en médecine qui souhaitent faire un stage en santé mondiale. C'est là une occasion d'acquérir des compétences et de développer des techniques utiles en dehors de leur programme officiel. Cette formule étant de plus en plus populaire, il s'avère nécessaire de structurer ces stages au choix, de définir des objectifs d'apprentissage précis et de préciser des résultats éducationnels adéquats.

Nous décrivons le stage au choix en médecine d'urgence pédiatrique internationale (International Pediatric Emergency Medicine Elective ou IPEME). II s'agit d'un nouveau stage en santé mondiale pour des étudiants du Canada et du MoyenOrient choisis dans le cadre d'un processus concurrentiel. Ils se réunissent à Toronto où ils poursuivent un programme d'études de 4 semaines. La structure de ce programme, créé en 2004, s'articule autour de 4 domaines : la médecine d'urgence pédiatrique, la santé mondiale, le leadership et la consolidation de la paix. Les rôles CanMEDS sont utilisés pour favoriser le dialogue interculturel, le réseautage et la coopération. Le stage répond à l'objectif du programme, qui consiste à utiliser la santé pour construire un pont pour la paix.

Nous mettons en évidence les leçons tirées de la planification des programmes et du processus de mise en œuvre et analysons l'incidence du programme en vue de développer d'autres stages internationaux au choix de ce genre.

Keywords: international medical education, peace through health, pediatrics

Medical students and residents are increasingly choosing to incorporate an international elective, often in developing countries. In 2006, over $27 \%$ of US medical graduates participated in an international health experience. ${ }^{1}$ The World Health Organization (WHO) recently called for stronger cross-cultural emphasis to encourage the worldwide training of "five-star" doctors who would integrate into their practices quality of care, emerging technologies, health promotion, individual and community health requirements, and efficient teamwork. ${ }^{2}$ There are potential benefits of undergraduate international health electives: they may promote cultural sensitivity, heighten appreciation of limited resources, and provide clinical exposure to a greater breadth of pathology than is typically seen in developed countries. ${ }^{3-6}$

Although residency electives generally have structured learning objectives and mentors attuned to trainee needs, such is not always the case for international

From the *Department of Medicine and Pediatrics, McMaster University; tUniversity of Toronto; $¥$ Peter A. Silverman Centre for International Health, Mount Sinai Hospital; and §Division of Pediatric Emergency Medicine, The Hospital for Sick Children, Toronto, ON.

Correspondence to: Dr. Rahim Valani, Hamilton Health Sciences Centre - General Site, 237 Barton Street East, Hamilton, ON L8L 2X2.

This article has been peer reviewed. 
health electives at the undergraduate level. In an attempt to remedy this, we developed a model for an undergraduate global health elective, the International Pediatric Emergency Medicine Elective (IPEME), based on the CanMEDS framework of competencies.

Several peace through health programs have been introduced in regions of conflict, many of them through the efforts of nongovernmental organizations as well as by McMaster University's medical faculty. ${ }^{7,8}$ They are designed to help conflicting geopolitical groups cooperate and reconcile differences through collaborative work involving local health care professionals. Less common are programs outside conflict regions, as in Toronto, where the IPEME was developed.

The IPEME is a 4-week elective that brings together eight Canadian, Israeli, Jordanian, and Palestinian medical students (two from each country). Table 1 provides the demographic information of the selected students from 2007 and 2008. The program provides a novel perspective to all participants, namely an International Health Elective for Middle Eastern students (as defined by an elective that is outside their local region) and a global health perspective for Canadian students. The students attend lectures, seminars, and workshops related to pediatric emergency medicine, global health, and research; observe patient care during shifts in a pediatric emergency department; and design a research project.

The curriculum design for IPEME was based on the CanMEDS roles. The CanMEDS reform in medical

\begin{tabular}{|c|c|c|}
\hline & 2007 & 2008 \\
\hline $\begin{array}{l}\text { Total number of } \\
\text { students }\end{array}$ & 8 & 8 \\
\hline$M / F$ & $3 / 5$ & $4 / 4$ \\
\hline \multicolumn{3}{|l|}{$\begin{array}{c}\text { Average medical } \\
\text { school year }\end{array}$} \\
\hline Canada* & 2 & 2 \\
\hline |srael $^{\dagger}$ & 5 & 6 \\
\hline Jordan $^{\dagger}$ & 5 & 5 \\
\hline Palestine $^{\dagger}$ & 5 & 5 \\
\hline \multicolumn{3}{|c|}{ Average age in years } \\
\hline All regions & 24.75 & 23.63 \\
\hline Canada & 27 & 22.5 \\
\hline Israel & 25.5 & 33 \\
\hline Jordan & 23.5 & 22.5 \\
\hline Palestine & 23 & 22.5 \\
\hline
\end{tabular}

education began in the 1990s and is now the standard for both generalist and specialist training programs across Canada. ${ }^{9}$ There are seven key competencies defined by the CanMEDs framework: Medical Expert, Advocate, Communicator, Collaborator, Manager, Scholar, and Professional. These roles are used by the Royal College of Physicians and Surgeons of Canada and the College of Family Physicians of Canada and have been adopted by other bodies internationally. In contrast, the five-star doctor, as defined by the $\mathrm{WHO}$, is a care provider, decision maker, communicator, community leader, and manager, whose roles are geared more toward primary care. The broad base of the defined roles, the portability across specialties, and international acceptance of the CanMEDS roles made it an ideal framework for developing the IPEME curriculum.

\section{PROGRAM OVERVIEW}

The aim of the IPEME is to foster cross-cultural dialogue, networking, and cooperation through a focus on pediatric emergency medicine, international health, and research methodology (Figure 1). Lectures, seminars, and case-based group discussions introduce participants to the subject matter, whereas practical workshops and supervised clinical interactions ensure hands-on experience and student interaction (Table 2). The students were divided into two groups, each group with one student from each region with the goal of formulating a research question by the end of the 4 weeks. They were encouraged to collaborate on the project on returning home.

Courses were taught by faculty that included physicians, nurses, members of nongovernmental organizations, hospital administrators, and allied health care workers. Follow-up seminars provided a venue for discussion. Faculty offered their expertise in both clinical and nonclinical sessions and gave students insights into interprofessional education. To remove any financial barriers, the program provided airfare, visa and medical examination fees, board, and food in addition to a weekly stipend to all participants.

\section{CURRICULUM FRAMEWORK AND DESIGN}

The overall objectives were delineated through dialogue among the faculty and local representatives from each region involved in the IPEME (See Table 3). The 


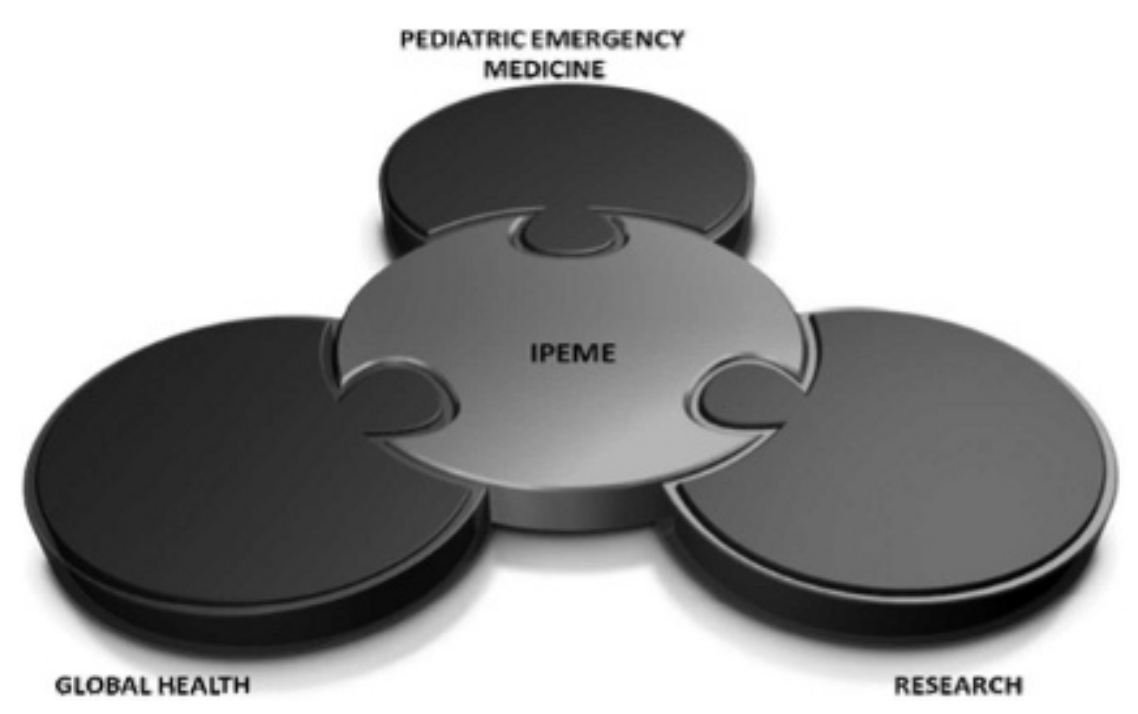

Figure 1. Core themes of the International Pediatric Emergency Medicine Elective (IPEME).
CanMEDS roles were then reviewed, and, based on the objectives plus the "peace through health" concept, specific instructional methods were developed. Aside from the group project that emphasized collaboration and scholarship, the majority of sessions were seminars and workshops. The schedule underwent revisions before and during the elective to ensure collaborative practice and to foster ongoing dialogue.
Each specific CanMEDS role was covered in the IPEME program (Table 4), with specific emphasis on the Communicator, Scholar, Advocate, and Manager roles. The program's emphasis on participation helped students from diverse regions become a cohesive group whose members would continue to network after they returned home. Each student had the opportunity to observe clinical practice to better understand the need

\begin{tabular}{|c|c|c|c|}
\hline & Pediatric Emergency Medicine & Global Health & Research Methodology \\
\hline Sessions & $\begin{array}{l}\text { Neonatal Jaundice } \\
\text { Pain } \\
\text { Neurological Emergencies } \\
\text { Fever in Children } \\
\text { Sepsis and Septic Shock } \\
\text { Burns } \\
\text { Pediatric Orthopedics } \\
\text { Dehydration/Gastroenteritis } \\
\text { Toxicology }\end{array}$ & $\begin{array}{l}\text { Disaster Medicine } \\
\text { Global Child Health } \\
\text { Health and Human Security } \\
\text { Peace Building: CISEPO Principles }\end{array}$ & $\begin{array}{l}\text { Introduction to Research Design } \\
\text { Evidence-Based Medicine }\end{array}$ \\
\hline Workshops & $\begin{array}{l}\text { An Introduction to Resuscitation } \\
\text { Casting and Splinting } \\
\text { Suturing Skills } \\
\text { Organizational/Management } \\
\text { Working in Interprofessional Teams } \\
\text { Breaking Bad News } \\
\text { Child Life in the Emergency } \\
\text { Department } \\
\text { Triage and Acuity in the Emergency } \\
\text { Department } \\
\text { Health/Human Rights in Hospital } \\
\text { Child Abuse and Neglect }\end{array}$ & $\begin{array}{l}\text { Networking Exercises } \\
\text { Conflict Resolution and Draining Techniques } \\
\text { Team-Building Activity } \\
\text { Intercommunal Relationships } \\
\text { Cultural Differences in Treating Patients }\end{array}$ & $\begin{array}{l}\text { Literature Search Strategies } \\
\text { Critical Appraisal Review } \\
\text { Presentation Skills } \\
\text { Research Proposal Development and Writing }\end{array}$ \\
\hline
\end{tabular}




\section{Table 3. Objective outcomes for IPEME students}

1. Demonstrate an understanding of peaceful collaboration using health care as the means.

2. Develop an understanding of research methodology

3. Acquire a knowledge of common conditions encountered in pediatric emergency medicine and an understanding of the specialty as a whole.

4. Determine, prioritize, and justify clinical decisions using best practice.

5. Use effective interpersonal and communication skills to interact positively with patients, families, and colleagues.

6. Demonstrate collaborative practices as a member of a multidisciplinary team.

7. Better understand the individual, organizational, and societal contexts of pediatric emergency health issues.

IPEME = International Pediatric Emergency Medicine Elective.

for collaborative practice. The team research project reinforced the concept of collaboration.

Scholarly activity was encouraged through a literature search and solving a health problem with international dimensions. Students learned how to work efficiently and complete assigned work in a timely fashion.

Students obtained a close-up view of professionalism in the health care field and learned to appreciate how physicians and other health care professionals worked together. They discussed their local practices and explained how these were partly determined by social, cultural, and religious beliefs. The fading of geopolitical barriers was evident throughout the program.

\section{PROGRAM EVALUATION}

Participants were asked weekly to evaluate each component of the program. Evaluations used a 5-point Likert scale (Table 5). Although these evaluations provided some insight into the delivery and satisfaction of the different facets of the program, it is still uncertain if the aims of the program were met. The students appeared to prefer practical and clinical sessions over seminars. A recent publication by our group looked specifically at changes in attitudes among the participants during the program. ${ }^{10}$

\section{DISCUSSION}

International health electives broaden the exposure of medical students to other regions' cultures, health care systems, and challenges, as well as providing opportunities for these students to enhance their own clinical skills and knowledge. ${ }^{11,12}$ These electives may also play a role in career choices, such as whether to work in primary care or in underserviced areas, in their own country or abroad., ${ }^{42-18}$ In addition to the personal and professional development of participants, a review of cross-cultural experiences showed that medical schools and the host population benefited. ${ }^{19}$

International electives do face several challenges. Besides requiring better curriculum design, they have to consider travel, financial, and institutional risks. Although not an international health elective in its truest sense, IPEME is a unique elective that provides a rigorous curriculum taught by local experts. Having students from different "sides" of an area of conflict in physical proximity to each other in a politically neutral environment ensured their safety and created an atmosphere in which open, friendly discussion could occur.

IPEME can serve as a model for programs examining the role of CanMEDS in undergraduate global health electives. Three components to which students drew attention in this initial venture were the shadow shifts, practical sessions, and group projects. Students felt that more direct contact with emergency department patients would have sharpened their skills and enabled them to contribute to clinical decisions. During the program's second year, the students were more involved in clinical care and received university credit for the elective. Given that students could not see the varied settings of care in each country, discussions on the differences in practice among the regions represented took place. The number of practical sessions has been increased. The difficulties of trying to run a research project on returning home have been removed by lowering the expectations for the regional research project and stressing the benefits of collaboration while still in Canada. In addition, a designated lead faculty preceptor has been appointed to help and guide each group during and after the month in Toronto.

\section{CONCLUSION}

International undergraduate medical electives require learning objectives based on a recognized framework to provide structure and direction to the experience. A structured educational plan that offers an opportunity for medical students from areas of conflict to meet on neutral ground and work together helped students gain 


\begin{tabular}{|c|c|c|}
\hline CanMEDS Criteria & Elective Objectives & Teaching Approach \\
\hline \multirow[t]{3}{*}{ Medical Expert } & Describe PEM as a specialty & Sessions: eg, Pain, Fever in Children \\
\hline & $\begin{array}{l}\text { Explain the management of common PEM } \\
\text { conditions }\end{array}$ & $\begin{array}{l}\text { Practical workshops: eg, An Introduction to } \\
\text { Resuscitation, Casting and Splinting }\end{array}$ \\
\hline & $\begin{array}{l}\text { Appreciate clinical decision making using best } \\
\text { practice models and evidence-based medicine }\end{array}$ & \\
\hline \multirow[t]{3}{*}{ Health Advocate } & $\begin{array}{l}\text { Demonstrate an understanding of peaceful } \\
\text { collaboration using health care as a vehicle }\end{array}$ & $\begin{array}{l}\text { Sessions: eg, Breaking Bad News, Child Life in the } \\
\text { Emergency Department, Health and Human Rights in } \\
\text { the Hospital Setting, Child Abuse and Neglect }\end{array}$ \\
\hline & $\begin{array}{l}\text { Reflect on the ways to understand the needs of } \\
\text { patients }\end{array}$ & \\
\hline & $\begin{array}{l}\text { Describe tools that can be used to advocate for } \\
\text { patient concerns }\end{array}$ & \\
\hline \multirow[t]{2}{*}{ Communicator } & $\begin{array}{l}\text { Demonstrate effective interpersonal and } \\
\text { communication skills to interact positively with } \\
\text { patients, families, and colleagues }\end{array}$ & $\begin{array}{l}\text { Sessions: eg, Breaking Bad News, Working in } \\
\text { Interprofessional Teams, Health and Human Rights in } \\
\text { the Hospital Setting, Intercommunal Relationships, } \\
\text { emergency medicine interaction with other services, } \\
\text { networking exercises, conflict resolution }\end{array}$ \\
\hline & $\begin{array}{l}\text { Apply common methods used to collaborate in small } \\
\text { groups }\end{array}$ & \\
\hline \multirow[t]{3}{*}{ Scholar } & Explain basic research skills & $\begin{array}{l}\text { Sessions: eg, introduction to research, critical appraisal } \\
\text { skills, literature search, literature review, research } \\
\text { design, presentation skills }\end{array}$ \\
\hline & $\begin{array}{l}\text { Synthesize and conceptualize a pediatric emergency } \\
\text { issue and develop researchable questions }\end{array}$ & $\begin{array}{l}\text { Group assignment: cross-border research project } \\
\text { planning, development, and implementation }\end{array}$ \\
\hline & $\begin{array}{l}\text { Appreciate geographic differences in the practice of } \\
\text { PEM }\end{array}$ & One-on-one mentoring \\
\hline \multirow[t]{3}{*}{ Manager } & $\begin{array}{l}\text { Demonstrate collaborative work in cross-cultural } \\
\text { teams }\end{array}$ & $\begin{array}{l}\text { Group assignment: cross-border research project } \\
\text { planning, development, and implementation }\end{array}$ \\
\hline & $\begin{array}{l}\text { Demonstrate how to set priorities and manage time } \\
\text { effectively }\end{array}$ & $\begin{array}{l}\text { Sessions: eg, chaplain session, conflict resolution, child } \\
\text { life, triage and acuity, disaster management, } \\
\text { presentation skills }\end{array}$ \\
\hline & $\begin{array}{l}\text { Discuss the individual, organizational, and societal } \\
\text { elements of pediatric emergency health issues }\end{array}$ & $\begin{array}{l}\text { One-on-one mentoring regarding project management, } \\
\text { priority setting, teamwork }\end{array}$ \\
\hline \multirow[t]{4}{*}{ Professional } & $\begin{array}{l}\text { List ethical issues encountered in clinical settings } \\
\text { and research environments }\end{array}$ & $\begin{array}{l}\text { Sessions: eg, conflict resolution, Health and Human } \\
\text { Rights in the Emergency Department, chaplain } \\
\text { session, networking exercise, emergency medicine } \\
\text { interaction with other services }\end{array}$ \\
\hline & $\begin{array}{l}\text { Demonstrate basic skills in managing conflicts of } \\
\text { interest }\end{array}$ & One-on-one mentoring \\
\hline & $\begin{array}{l}\text { Recognize and respect different cultural and religious } \\
\text { values }\end{array}$ & Role modeling \\
\hline & $\begin{array}{l}\text { Adopt skills to recognize and deal with } \\
\text { unprofessional behaviours in practice }\end{array}$ & \\
\hline \multirow[t]{4}{*}{ Collaborator } & $\begin{array}{l}\text { Demonstrate collaborative practice as a member of a } \\
\text { multidisciplinary team }\end{array}$ & $\begin{array}{l}\text { Group assignment: cross-border research project } \\
\text { planning, development, and implementation }\end{array}$ \\
\hline & Interprofessional & Role modeling \\
\hline & Cross-cultural & \\
\hline & Across borders & \\
\hline
\end{tabular}

a broad exposure to other cultures, disease management, and health care systems and better appreciate the difficulties under which others work. The residential international elective approach and role modeling provided opportunities to integrate the CanMEDS roles into both formal and informal curriculum activities and encouraged development of multiple skills. 


\begin{tabular}{|c|c|c|c|}
\hline Component & $\begin{array}{c}2007(n=5) \\
\text { Mean (SD) }\end{array}$ & $\begin{array}{c}2008(n=8) \\
\text { Mean (SD) }\end{array}$ & $\begin{array}{c}\text { Cumulative }(N=13) \\
\text { Mean }(S D)\end{array}$ \\
\hline Shadow shifts & $4.2(0.8)$ & $4.75(0.7)$ & $4.54(0.78)$ \\
\hline Weekly rounds & $4.2(0.8)$ & $4.25(1.0)$ & $4.23(0.93)$ \\
\hline Team-building activities & $4.8(0.4)$ & $4.38(0.7)$ & $4.53(0.66)$ \\
\hline Practical sessions & $5(0)$ & $4.38(1.2)$ & $4.61(0.96)$ \\
\hline Project review sessions & $4.2(1.3)$ & $4.0(0.5)$ & $4.08(0.86)$ \\
\hline
\end{tabular}

Competing interests: None declared.

\section{REFERENCES}

1. Association of American Medical Colleges. Graduation questionnaire (GQ). Available at: http://www.aamc.org/data/ gq/start.htm (accessed April 21, 2008).

2. Boelen C. Medical education reform: the need for global action. Acad Med 1992;67:745-9.

3. Niemantsverdriet S, van der Vleuten CP, Majoor GD, et al. The learning processes of international students through the eyes of foreign supervisors. Med Teach 2006;28:e104-11.

4. Miranda JJ, Yudkin JS, Willott C. International health electives: four years of experience. Travel Med Infect Dis 2005;3:133-41.

5. Chiller TM, De Mieri P, Cohen I. International health training. The Tulane experience. Infect Dis Clin North Am 1995;9:439-43.

6. Torjesen H. An international health story from Case Western Reserve University. Infect Dis Clin North Am 1995;9:433-7.

7. Blumenthal S, Safdi S. Peace through bealth: a mapping of cooperative health programs in Palestine and Israel. A report of the Palestine/Israel Health Initiative. 2008. Available at: http://www. thepresidency.org/storage/documents/PeaceThroughHealth/ Peace_Through_Health.pdf (accessed November 2010).

8. Santa Barbara J. Medicine, peace and public policy. Croat Med 7 2006;47:352-5.

9. Frank JR, editor. The CanMEDS 2005 Physician Competency Framework. Better physicians. Better care. Ottawa: The Royal College of Physicians and Surgeons of Canada, 2005.
10. Valani R, Verma M, Sriharan A, et al. Enabling change in attitudes among medical students during a pediatric emergency medicine elective. Isr 7 Emerg Med 2009;9: $22-9$.

11. Thompson MJ, Huntington MK, Hunt DD, et al. Educational effects of international health electives on U.S. and Canadian medical students and residents: a literature review. Acad Med 2003;78:342-7.

12. Smith JK, Weaver DB. Capturing medical students' idealism. Ann Fam Med 2006;4Suppl 1:S32-7; discussion S58-60.

13. Dodard M, Vulcain A, Fournier A. Project Medishare: a volunteer program in international health at the University of Miami. Acad Med 2000;75:397-401.

14. Weir E. A summer in India. CMAJ 1996;155:785-7.

15. Imperato PJ. A third world international health elective for U.S. medical students. The 16-year experience of the State University of New York, Health Science Center at Brooklyn. 7 Community Health 1996;21:241-68.

16. Bateman C, Baker T, Hoornenborg E, et al. Bringing global issues to medical teaching. Lancet 2001;358:1539-42.

17. Harth SC, Leonard NA, Fitzgerald SM, et al. The educational value of clinical electives. Med Educ 1990;24: 344-53.

18. Godkin M, Savageau J. The effect of medical students' international experiences on attitudes toward serving underserved multicultural populations. Fam Med 2003;35:273-8.

19. Mutchnick IS, Moyer CA, Stern DT. Expanding the boundaries of medical education: evidence for cross-cultural exchanges. Acad Med 2003;78(10 Suppl):S1-5. 